\title{
STUDI BIOINFORMASI URUTAN ASAM AMINO DAN STRUKTUR 3D PROTEIN ALDOLASE KELAS II (AIdII) DARI Uncultured Acidilobus sp.
}

\author{
Nishia Waya Meray ${ }^{* 1,2}$, Suharti $^{2,3}$, Akhmaloka $^{2}$ \\ ${ }^{1}$ Program Studi Farmasi, Universitas Mulia \\ ${ }^{2}$ Tim Penelitian Biokimia, Fakultas Matematika dan Ilmu Pengetahuan Alam, Institut Teknologi Bandung \\ ${ }^{3}$ Program Studi Kimia, Fakultas Sains dan Ilmu Komputer, Universitas Pertamina \\ *email : nishia@universitasmulia.ac.id
}

Received 1 November 2021

Accepted 9 Desember 2021

\begin{abstract}
Abstrak
Pada penelitian sebelumnya fragmen gen 1,9 kb telah berhasil diisolasi dari Kawah Domas, Jawa Barat melalui pendekatan metagenom. Fragmen tersebut diketahui mengandung daerah Open Reading Frame (ORF) utuh dari gen pengkode aldolase kelas II dari uncultured Acidilobus sp. yang kemudian disebut sebagai aldII. Fragmen gen aldII tersebut berhasil diekspresikan menjadi protein termostabil aldolase kelas II yang kemudian disebut sebagai AldII. Penelitian ini bertujuan untuk melakukan studi bioinformasi terhadap protein AldII tersebut. Protein AldII kemudian diketahui memiliki massa molekul $\sim 21,2 \mathrm{kDa}$ dengan rumus molekul $\mathrm{C}_{940} \mathrm{H}_{1539} \mathrm{~N}_{261} \mathrm{O}_{281} \mathrm{~S}_{8}$. Total residu bermuatan negatif (Asp + Glu) sebanyak 22 residu, sedangkan total residu bermuatan positif (Arg + Lys) adalah 18 residu. Nilai pI teoritis AldII sebesar 5,86. Hasil perhitungan indeks kestabilan protein ini adalah 36,61 dan diklasifikasikan sebagai protein yang stabil. Lewat penjajaran dengan homologi terdekat, ditemukan daerah lestari yang dapat menunjukan residu yang mungkin berperan dalam pengikatan logam dan sisi aktif. Prediksi struktur 3D dilakukan secara ab initio, menunjukan adanya 6 struktur $\beta$-sheet dan 6 struktur $\alpha$-heliks. Dengan demikian dapat disimpulkan bahwa protein AldII dari uncultured Acidilobus sp. diduga memiliki aktivitas enzimatik.
\end{abstract}

Kata kunci: aldolase kelas II, Acidilobus sp., bioinformasi, sisi aktif, struktur 3D

\begin{abstract}
In previous research, $1.9 \mathrm{~kb}$ gene fragment was isolated from Domas Crater, West Java through a metagenomic approach. These fragments are known contain Open Reading Frame (ORF) region of the coding gene for aldolase class II from uncultured Acidilobus sp. which is then referred to as aldII. The aldII gene fragment was successfully cloned and expressed into a thermostable class II aldolase protein which is then referred to as AldII. This study aims to conduct a bioinformation study of the AldII protein. AldII protein have a molecular mass of $\sim 21.2 \mathrm{kDa}$ with the molecular formula $\mathrm{C}_{94} 0 \mathrm{H}_{1539} \mathrm{~N}_{261} \mathrm{O}_{281} \mathrm{~S}_{8}$. The total negatively charged residues (Asp + Glu) were 22 residues, while the total positively charged residues (Arg + Lys) were 18 residues. The theoretical pI value of AldII is 5.86. The calculation result showed that, the protein stability index is 36.61 and it classified as a stable protein. By alignment with the closest homology, it was found that the conserved region could show residues that might play a role in metal binding site and the active site. Prediction of the 3D structure performed with ab initio method, showed that there were $6 \beta$-sheet structures and $6 \alpha$-heliks structures. Thus, it can be concluded that AldII protein from uncultured Acidilobus sp. is suspected to have enzymatic activity.
\end{abstract}


Keywords: class II aldolase, Acidilobus sp., bioinformation, active site, 3D structure

\section{Pendahuluan}

Indonesia merupakan negara dengan banyak daerah geotermal dengan kondisi ekstrim yang menjadi habitat mikroorganisme termofilik. Enzim termostabil yang dihasilkan menjadi pusat perhatian karena banyak proses industrial dilakukan pada temperatur tinggi. (Basen et al, 2012). Pada penelitian sebelumnya fragmen gen $1,9 \mathrm{~kb}$ telah berhasil diisolasi dari Kawah Domas, Jawa Barat melalui pendekatan metagenom (Suharti et al, 2015). Fragmen tersebut diketahui mengandung daerah Open Reading Frame (ORF) utuh dari gen pengkode aldolase kelas II yang kemudian disebut sebagai aldII. Fragmen gen aldII tersebut berhasil diekspresikan menjadi protein termostabil aldolase kelas II yang kemudian disebut sebagai AldII. Penelitian lanjutan yang dilakukan terhadap AldII menunjukan bahwa AldII bersifat termostabil, karena tidak terdenaturasi setelah dipanaskan pada temperatur $60{ }^{\circ} \mathrm{C}$ selama 30 menit (Suharti et al, 2015).

Aldolase sendiri merupakan kelompok enzim liase yang mengkatalisis reaksi bolak balik fruktosa-1,6-bifosfat (F-1,6PB) menjadi gliseraldehid-3-fosfat (G3P) dan dihidroksiaseton fosfat (DHAP) secara stereoselektif. Saat ini aldolase banyak diaplikasikan dalam industri pembuatan turunan fruktosa dan industri farmasi. Penggunaan aldolase dalam industri farmasi dikarenakan sifat stereoselektif enzim aldolase salah satunya adalah untuk sintesis statin (obat penurun kolesterol). Untuk kebutuhan industri dibutuhkan aldolase yang bersifat termostabil, dan aldolase yang bersifat termostabil tersebut telah berhasil diisolasi dari berbagai mikroorganisme Archaea antara lain Bacillus cereus, Aeropyrum pernix, Pyrobaculum aerophilum, Thermotoga maritima dan Hyperthermus butylicus (Wang et al, 2010).

Artikel ini membahas mengenai studi bioinformasi protein AldII dari uncultured
Acidilobus sp., yang meliputi analisa homologi urutan asam amino AldII, penentuan sifat - sifat biokimia protein AldII dan prediksi struktur 3D protein AldII.

\section{Metode Penelitian \\ Bahan}

Bahan penelitian yang digunakan dalam penelitian ini adalah urutan gen dari uncultured Acidilobus sp. yang telah berhasil di sequencing dari penelitian sebelumnya. Urutan gen aldII sudah ada dalam NCBI dengan nomor identitas KP893071 (Suharti et al, 2015).

\section{Penjajaran Urutan Asam Amino AldII dengan Homologi Terdekat \\ Gen aldII ditranslasi secara in silico} menggunakan program BLASTp yang disediakan oleh National Center for Biotechnology Information Search database (NCBI). Urutan asam amino AldII yang dihasilkan kemudian disejajarkan dengan homologi terdekat yang telah diketahui dari hasil penelitian sebelumnya, yaitu dengan spesies Acidilobus saccharovorans (Asac); Aeropyrum pernix (Aper); Pyrolobus fumarii (Pfum); Caldivirga maquilingensis (Cmaq); Ignisphaera aggregans (Iag) (Suharti et al, 2015). Penjajaran urutan asam amino protein AldII dianalisis menggunakan program ClustalX dan divisualisasi menggunakan program Genedoc.

\section{Penentuan Sifat-Sifat Biokimia Protein AldII \\ Sifat-sifat biokimia protein AldII yang meliputi deduksi urutan asam amino, penentuan berat molekul, dan penentuan nilai pI dianalisa dengan menggunakan progam yang disediakan oleh ProtParam pada http://www.expasy.org/tools/protparam.ht $\underline{\mathrm{ml}}$.}


Prediksi Struktur 3D AldII

Prediksi struktur 3D dilakukan dengan menggunakan pendekatan $a b$ initio pada progam QUARK melalui situs http://zhanglab.ccmb.med.umich.edu/QU ARK/.

\section{Hasil dan Pembahasan}

Penjajaran Urutan Asam Amino AldII dengan Homologi Terdekat

Gen pengkode aldolase kelas II (aldII) hasil pendekatan metagenom yang diperoleh dari penelitian sebelumnya merupakan gen sepanjang 639 pasang basa yang disisipkan ke dalam vektor ekspresi pET30-a(+). Sekuen dari gen aldII sudah ada dalam NCBI dengan nomor identitas KP893071 seperti yang ada pada Gambar 1. Setelah ditranslasi menggunakan BLASTp, menghasilkan protein aldolase kelas II dengan massa molekul $\sim 21,2 \mathrm{kDa}$ seperti yang ditunjukan pada Gambar 2.

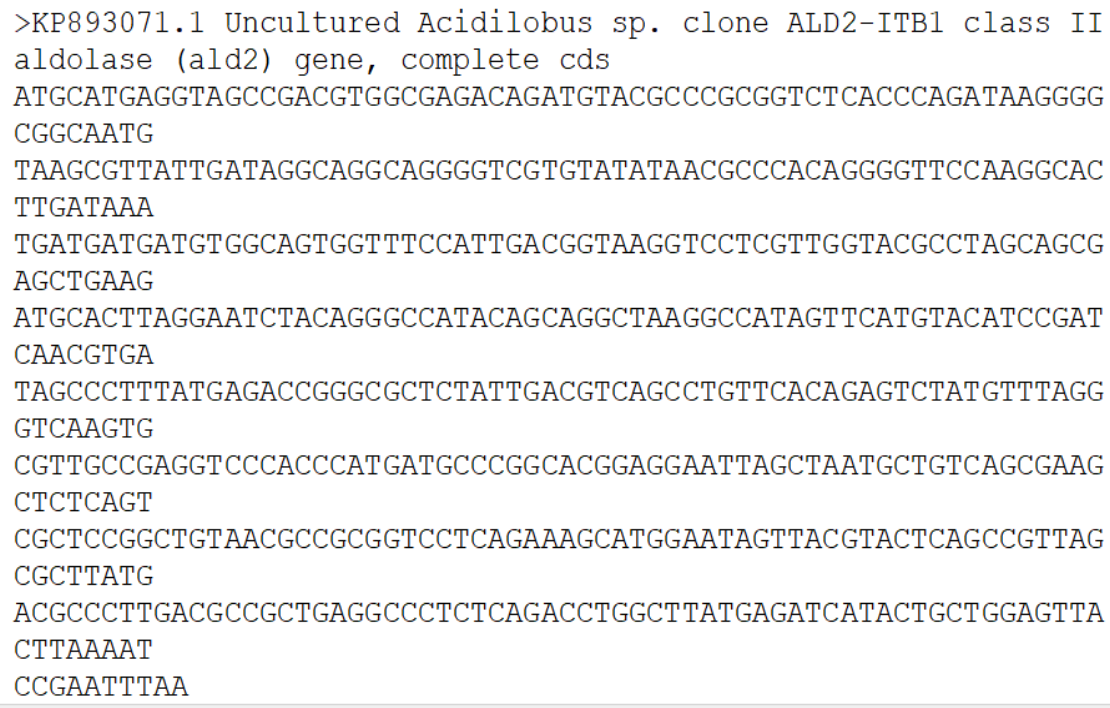

Gambar 1. Sekuen gen aldII
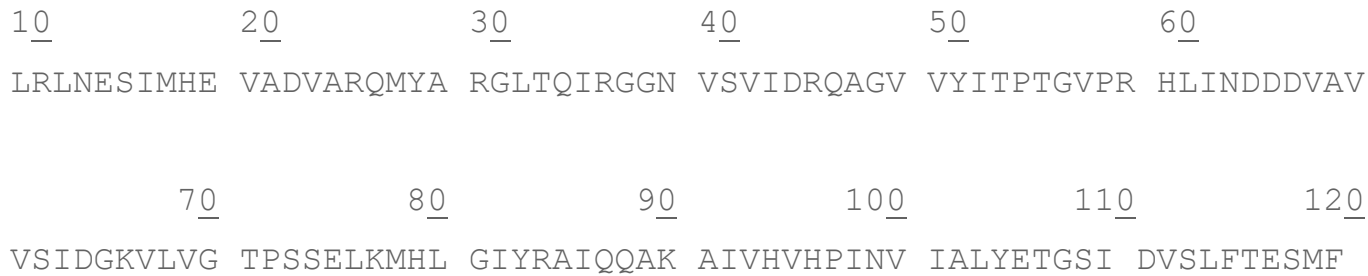

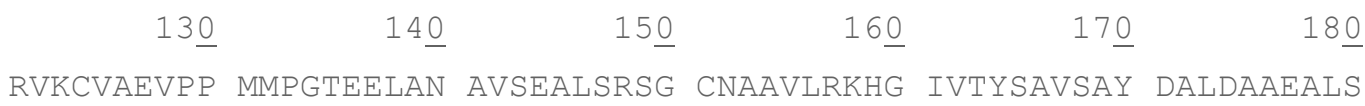

190

\section{DLAYEIILLE LLKIRI}

Gambar 2. Urutan asam amino AldII. Notasi asam amino dinyatakan dalam notasi 1 huruf

Berdasarkan hasil penelitian terdahulu (Suharti et al, 2015), gen aldII yang mengkode protein AldII memiliki homologi terdekat dengan gen aldolase kelas II yang berasal dari mikroba Acidilobus sp. Diketahui Acidilobus sp. merupakan jenis spesies yang termasuk dalam Kingdom Archaea. Karena hal 
tersebut maka, penjajaran urutan asam amino AldII dilakukan dengan urutan asam amino protein Aldolase kelas II pada beberapa spesies Kingdom Archaea. Penjajaran homologi terdekat dilakukan untuk mempelajari daerah lestari dan residu yang mungkin berperan dalam pengikatan logam. Hasil penjajaran menunjukkan bahwa ada tiga residu yang mungkin berperan dalam pengikatan logam, antara lain residu Aspartat (D) , Glutamat (E) dan Histidin (H). Hal ini dikarenakan ketiga residu tersebut merupakan asam amino yang bermuatan negatif, sehingga dapat berikatan dengan logam yang bermuatan positif. Penjajaran asam amino ditunjukan pada Gambar 3

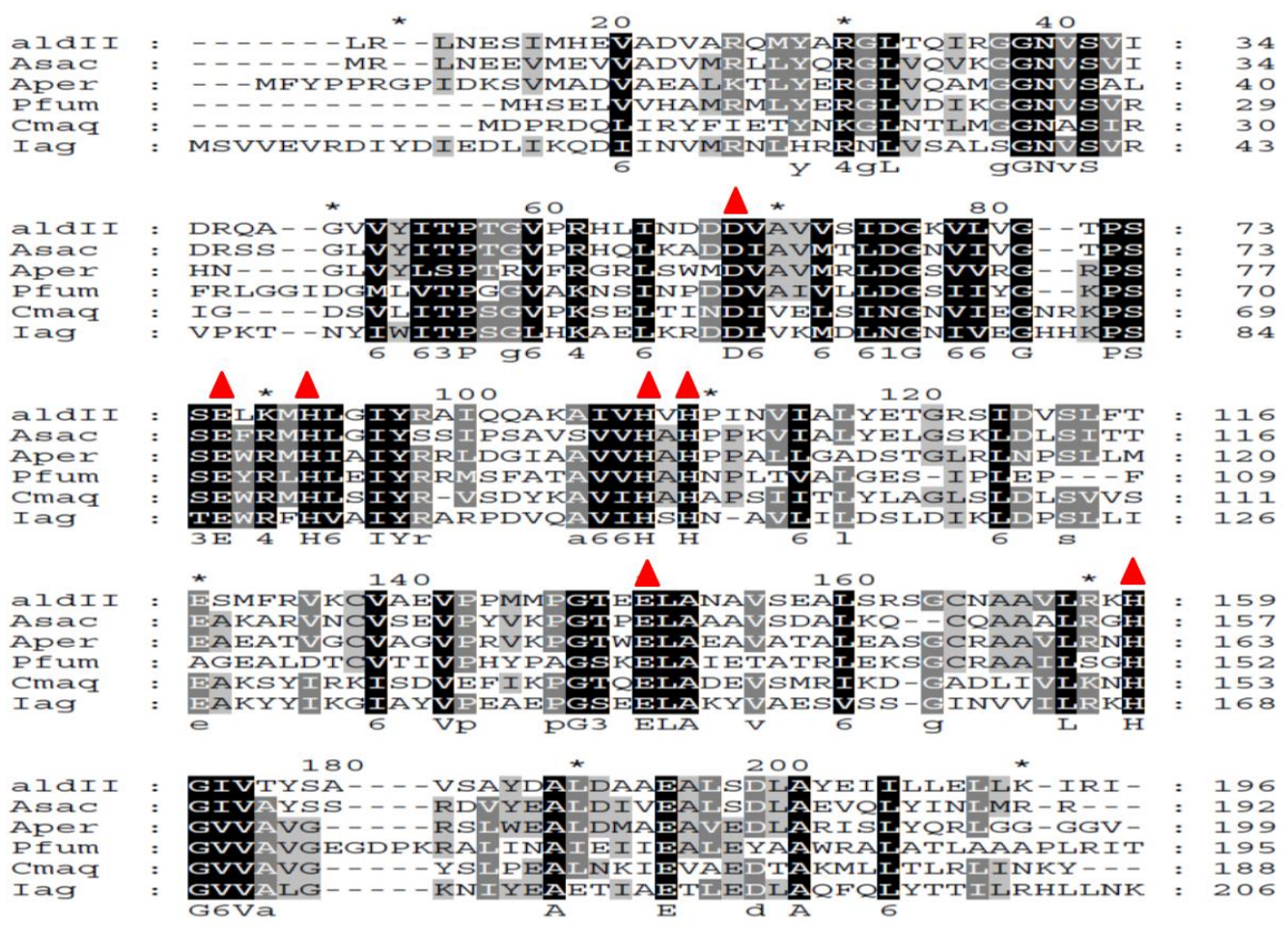

Gambar 3. Penjajaran urutan asam amino AldII dengan aldolase kelas II homologi terdekat. Asac, Acidilobus saccharovorans; Aper, Aeropyrum pernix; Pfum, Pyrolobus fumarii; Cmaq, Caldivirga maquilingensis; Iag, Ignisphaera aggregans. Segitiga merah menunjukkan residu yang berperan dalam pengikatan logam. Bintang menunjukan residu yang berperan dalam pengikatan $\mathrm{Zn}^{2+}$

\section{Penentuan Sifat-sifat Biokimia Protein AldII}

Hasil deduksi urutan nukleotida aldII menghasilkan protein AldII yang terdiri atas 196 asam amino (Gambar 2). Penentuan sifat-sifat biokimia AldII dilakukan dengan menganalisis urutan tersebut menggunakan webserver Protparam pada situs ExPASy. Hasil analisis menghasilkan data berat molekul AldII sebesar $\sim 21,2 \mathrm{kDa}$ dengan rumus molekul $\mathrm{C}_{940} \mathrm{H}_{1539} \mathrm{~N}_{261} \mathrm{O}_{281} \mathrm{~S}_{8}$. Total residu bermuatan negatif (Asp + Glu) sebanyak 22 residu, sedangkan total residu bermuatan positif (Arg + Lys) adalah 18 residu. Nilai pI teoritis AldII sebesar 5,86. Hasil perhitungan indeks kestabilan protein ini adalah 36,61 dan diklasifikasikan sebagai protein yang stabil. Indeks kestabilan diprediksi berdasarkan panjang urutan asam amino dan komposisi dipeptida dengan 
menggunakan rumus tertentu (data mengenai rumus penentuan kestabilan protein disediakan dalam https://web.expasy.org/protparam/protpar am-doc.html). Apabila nilai indeks dibawah 40 tergolong sebagai protein yang stabil sedangkan nilai indeks diatas 40 tergolong sebagai protein yang tidak stabil (Guruprasad et al, 1990).

\section{Prediksi Struktur 3D AldII menggunakan pendekatan ab initio}

Sampai saat ini, hanya sedikit protein aldolase dari kingdom Archaea yang berhasil dikristalkan. Karena database mengenai struktur aldolase dari kingdom Archaea masih sedikit dan urutan asam amino dari AldII tergolong pendek maka penentuan struktur 3D dilakukan dengan menggunakan pendekatan $a b$ initio yang terdapat pada progam QUARK melalui http://zhanglab.ccmb.med.umich.edu/QU ARK. Progam ini dapat memprediksikan struktur 3D protein tanpa menggunakan templat dari struktur protein yang telah ada sebelumnya. Hasil deduksi protein AldII diprediksikan memiliki struktur 3D yang terdiri atas 6 struktur $\beta$-sheet dan 6 struktur $\alpha$-heliks seperti yang ditunjukan pada Gambar 4.

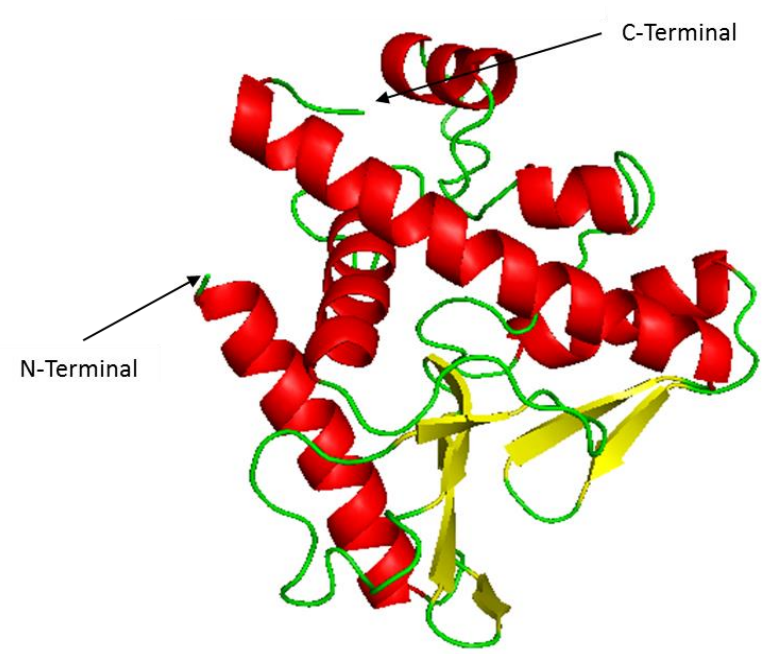

Gambar 4. Struktur 3D protein AldII secara ab initio. Warna merah menunjukkan struktur $\alpha$-heliks. Warna kuning menunjukkan struktur $\beta$-sheet. Warna hijau menunjukkan loop. Dianalisis menggunakan progam Pymol.

Diketahui aldolase kelas II pada Kingdom Bacteria memiliki struktur dimer, dengan setiap monomer mengikat satu atom logam (Berry et al, 1993; Siebers et al, 2001). Pada Kingdom Archaea, struktur tiga dimensi aldolase yang berhasil ditentukan hingga saat ini hanya aldolase kelas I. Aldolase kelas I Archaea yang berhasil dikristalkan antara lain, Sulfolobus solfataricus (tetramer), Thermoproteus tenax (pentamer), Aeropyrum pernix (tetramer), Pyrobaculum aerophilum (dimer) (data mengenai struktur diperoleh lewat Protein Data Bank pada situs http://www.rscb.org/pdb/home/.

\section{Kesimpulan}

Hasil studi bioinformasi menunjukan bahwa protein AldII meupakan protein yang stabil. Temuan daerah lestari dapat menunjukan residu yang mungkin berperan dalam pengikatan logam dan sisi aktif. Prediksi struktur 3D yang dilakukan secara $a b$ initio menunjukan adanya 6 struktur $\beta$-sheet dan 6 struktur $\alpha$-heliks. Dengan demikian dapat disimpulkan bahwa protein AldII dari uncultured Acidilobus sp. diduga memiliki aktivitas enzimatik. 


\section{Daftar Pustaka}

Basen, M., Sun, J. dan Anne, M. W. W. A., 2012. Engineering a Hyperthermophilic Archaeon for Temperature-Dependent Product Formation, mBio, 3, 1-8

Suharti, Meray N. W., Nurbaiti S., Akhmaloka., 2015. Cloning and Expression of A Novel Gene Encoded Thermostable Archaeal Aldolase Class II from Natural Sample, Bioscience Biotechnology Research Asia, 12 (2), 1023-1029.

Wang, Q., Chen, R., Du, P., Wu, H., Pei, X., Yang, B., Yang, L., Huang, L., Liu, J. dan Xie, T., 2010. Cloning and Characterization of Thermostabledeoxy-D-ribose-5-phosphate Aldolase from Hyperthermus butylicus, African Journal of Biotechnology, 9, 2898-2905.
Guruprasad, K., Reddy, B.V.B. and Pandit, M.W., 1990. Correlation Between Stability of a Protein and its Dipeptide Composition: A Novel Approach for Predicting In Vivo Stability of a Protein from its Primary Sequence. Protein Eng. 4,155-161.

Berry, A. dan Marshall, K. E., 1993. Identification of Zinc-Binding Ligands In The Class II Fructose-1,6Bisphosphate Aldolase of Escherichia coli. Federation of European Biochemical Socteties, 318, 11-16.

Siebers, B., Brinkmann, H., Dorr, C., Tjaden, B., Lilie, H., Oost, J. dan Verhees, C. H., 2001. Archaeal Fructose-1,6-bisphosphate Aldolases Constitute a New Family of Archaeal Type Class I Aldolase. The Journal of Biological Chemistry, 276, 28710 28718 